\title{
Biology and bulb production of Eleutherine bulbosa (Iridaceae), a native species from Borneo, Indonesia
}

\author{
Ni Made Armini Wiendi ${ }^{1 *}$ (), Nessa Maulida ${ }^{1}$ (D), Krisantini Krisantini ${ }^{1}$ (C)
}

${ }^{1}$ IPB University Jalan Meranti, Kampus IPB Dramaga, Faculty of Agriculture, Department of Agronomy and Horticulture, Bogor, Indonesia.

\begin{abstract}
Eleutherine bulbosa is a known ornamental plant of the Iris family, which originated from Central Borneo, Indonesia. The bulbs of E. bulbosa have long been used as a medicinal source by the local people of Borneo. Despite its known medicinal and other values, studies on the morphology and efficiency in bulb production of this species are limited. The aims of our study are to examine the vegetative and reproductive morphology of E. bulbosa, and to determine the effect of various dosages of NPK fertilizer on flowering and bulb production. The plants were grown in pots using potting mix consists of equal volume of burnt rice hulls, cocopeat, and organic manures (1:1:1). Our study showed that $E$. bulbosa has a cymose rhipidium inflorescence with 25-50 mm long peduncles, have 3-4 umbel on the secondary axis, each consists of 10-12 florets that opens in turn every day. Florets are 20-30 mm long, 20 $\mathrm{mm}$ in diameter, $10-15 \mathrm{~mm}$ pedicels, and short-lived. The perianth is white, about $25 \mathrm{~mm}$ wide with yellow anthers and stigma. Fruits were not formed during the duration of the study. NPK fertilizer application at the lowest dose of $1 \mathrm{~g}$ per pot had promoted earlier shoot emergence and vegetative growth, including plant height, leaf number, leaf size, number of tillers, and bulb production compared to control (no fertilizer). Application of fertilizer at 1 and $2 \mathrm{~g}$ per plant significantly promoted earlier flowering, whereas application at $3 \mathrm{~g}$ per plant delayed and reduced the proportion of flowering plants. The results of this study can aid in taxonomic identification and efficient cultivation of this plant for uses as potted flowering ornamentals or bulb production for different purposes. Higher cultivation and reduced wild harvesting can result in the conservation of this species.
\end{abstract}

Keywords: bawang Dayak, Iridaceae, nitrogen.

\section{Resumo}

Biologia e produção de bulbos de Eleutherine bulbosa (Iridaceae), uma espécie nativa de Bornéu, Indonésia Eleutherine bulbosa é uma espécie ornamental da família Iridaceae originária de Bornéu Central, Indonésia. Os bulbos de $E$. bulbosa são usados há muito tempo com finalidade medicinal pela população local de Bornéu. Apesar de ser conhecida pelos valores medicinais, estudos de morfologia e eficiência da produção de bulbos dessa espécie são limitados. O objetivo desse estudo é caracterizar a morfologia vegetativa e reprodutiva de E. bulbosa, e avaliar o efeito de doses do fertilizante NPK no florescimento e produção de bulbos. As plantas cresceram em vasos com substratos com proporções iguais de casca de arroz, rejeitos de coco, esterco orgânico (1:1:1). O estudo demonstrou que $E$. bulbosa apresenta inflorescência rhipidium cimosa ripídio com pedúnculos de 25-50 mm de comprimento, tem 3-4 umbelas no eixo secundário, cada uma com 10-12 flores pequenas que se abrem em turnos todos os dias. As flores têm 20-30 mm de comprimento, $20 \mathrm{~mm}$ de diâmetro, pedicelos de 10-15 mm e são efêmeras. O perianto é branco, com cerca de $25 \mathrm{~mm}$ de largura com anteras amarelas e estigma. Os frutos não se formaram durante o estudo. A aplicação do fertilizante NPK na dose mais baixa de $1 \mathrm{~g}$ por vaso promoveu a emergência de brotos e crescimento vegetativo mais precoces, incluindo a altura das plantas, número e tamanho de folhas, número de perfilhos foliares e produção de bulbos em comparação com o controle. A aplicação de 1 e $2 \mathrm{~g}$ de NPK por planta promoveu significativamente o florescimento mais precoce, enquanto a aplicação de 3 g por planta atrasou e reduziu a proporção de plantas com flores. Os resultados deste estudo são úteis para a identificação taxômica e cultivo eficiente dessa espécie para uso como flor envasada ou produção de bulbos para diferentes propósitos. O cultivo eficiente e a redução do extrativismo pode resultado na conservação desta espécie.

Palavras-chave: bawang Dayak, Iridaceae, nitrogen.

*Corresponding author: nmarmini@gmail.com 


\section{Introduction}

Eleutherine bulbosa (Mill.) Urb. is a species of flowering plant belonging to the family Iridaceae. It grows in the forests of Borneo, Indonesia (Kuntorini et al., 2016). It is also distributed in the Amazon region and has been included in the list of medicinal plants of interest in the National Health System of Brazil (Couto et al., 2016). The synonyms of E. bulbosa are Eleutherine plicata (Sw.) Klatt, Sisyrinchium bulbosum Mill. and Sisyrinchium palmifolium L. (Bingham et al., 2020).

The bulbs of $E$. bulbosa have widely been used for its medicinal properties throughout the world including Africa and Asia (Rani and Nair, 2016) and in Brazil (folk phototherapy), especially in the Amazonian region (Malheiros et al., 2015). The Dayaks or Dayuh (native Borneo people) have been using for generations the bulb juice or the boiled water from the bulbs as traditional medicines. The bulbs are also traded to other islands in Indonesia, particularly Java, due to the high demand for the bulbs. Bulbs has purplish red color with a bitter taste and pungent odor. The stellate flowers are white and fragrant; hence the flowering plants could be used as ornamental potted flowers or landscape plants.

Biological activities of the bulb extracts have been reported, including inhibit bacterial growth particularly Staphylococcus aureus, Escherichia coli, and Pseudomonas aeruginosa (Jiang et al., 2020). E. bulbosa bulb extracts could increase bone calcium level and bone weight (Bahtiar and Annisa, 2018), decrease the lipid profile of hypoestrogenic of rat, due to binding of eleutherinol to the estrogen receptors (Purnamasari and Bahtiar, 2018). The biological activities of E. bulbosa bulb extracts was correlated to its antioxidant content, including flavonoids and phenols (Preethy et al., 2016; Shi et al., 2018). Chen et al. (2018) isolated five new naphthalene derivatives from $E$. bulbosa bulbs, named eleutherols and eleuthinones, whereas Kamarudin et al. (2020) revealed eight biologically active constituents i.e., eleutherine, gallic acid, chlorogenic acid, quercetin, kaempferol, rutin, epicatechin gallate, and myricetin.

Eleutherine bulbosa is considered easy to grow crop, and is believed to readily adapt to various environment, so they are usually cultivated with minimal care (Noosar and Adi, 2015; Putra, 2018). The bulbs have been cultivated traditionally, but also been harvested from the natural habitat to meet the market demand. Studies on the growth and morphology of E. bulbosa plant and flower, and optimization of cultural practices are hardly available. Plant nutrition is essential for optimal plant growth and production, therefore information on the correct time and rate of fertilizer application is important for the efficiency of nutrient uptake. The aims of our study are to study the morphology, growth and flowering of E. bulbosa, and to determine whether growth and bulb production could be improved with fertilizer application. Knowledge from this study would be useful for easy identification and conservation of this species, to reduce wild harvesting, and for potential cultivation of $E$. bulbosa for potted ornamentals or bulb production.

\section{Materials and Methods}

The study was conducted in a greenhouse at the Department of Agronomy and Horticulture nursery, IPB University, at Cikabayan, Bogor, West Java, Indonesia, from February to December 2018. Plants were exposed at environmental conditions maintained at $27-35^{\circ} \mathrm{C}$ for the average daily temperature, $45 \%-66 \%$ for humidity, and $200-270$ $\mu \mathrm{mol} \mathrm{m} \mathrm{m}^{-2} \mathrm{~S}^{-1}$ for the average light intensity. Prior to planting, the bulbs were dipped in Dithane ${ }^{\circledR}$ F-45 (a.i. mancozeb) at $2 \mathrm{~g} \mathrm{~L}^{-1}$ for \pm 5 minutes to protect the bulbs from fungal infection.

A total of 120 bulbs of E. bulbosa with $\pm 50 \mathrm{~mm}$ in length and $\pm 30 \mathrm{~mm}$ in diameter were obtained from Pontianak, West Borneo, Indonesia. These bulbs were planted individually in $1 \mathrm{~L}$ pots, representing 3 fertilizer treatments and 1 control of 30 pots per treatment. The substrate used was equal volume of burnt rice hulls, cocopeat, and organic manures $(1: 1: 1)$. The substrate was pasteurized prior to use. The fertilizer treatments consist of 1,2 and $3 \mathrm{~g}$ per pot of commercially available solid NPK applied at planting and 8 weeks after planting. Application of fertilizer at planting used NPK with equal proportion of nitrogen, phosphorus and potassium (16-16-16). Application of fertilizer at 8 weeks after planting, i.e., when the plants had entered the generative stage, used NPK with a higher potassium proportion (12-12-17). Both fertilizers contained trace elements of $\mathrm{MgO}$, Borate, $\mathrm{CuSO}_{4}$, and $\mathrm{ZnSO}_{4}$. A fourth setup with no fertilizer was used as control. The plants were watered every two days; weed control was conducted when necessary. Observations of plant morphology were conducted. Harvesting was done after $>90 \%$ of the plants have initiated flowers.

Before starting experiment three samples were collected from the thoroughly substrate to make a representative composite soil sample that had a total $\mathrm{N}, \mathrm{P}$, and $\mathrm{K}$ content of $1.39 \mathrm{~g} \mathrm{~kg}^{-1}, 730 \mathrm{mg} \mathrm{kg}^{-1}$, and $190 \mathrm{mg} \mathrm{kg}^{-1}$, respectively. The total $\mathrm{N}$ was determined using Kjehdahl method (Church et al., 2017), whereas total $\mathrm{P}$ and $\mathrm{K}$ using $\mathrm{HNO}_{3}$ extraction method (Clinton et al., 2017).

Data related to the vegetative and reproductive morphology of E. bulbosa were collected. For vegetative morphology, growth habit and growth measurements were done by recording the number of days it took for shoots to emerge after planting. Other characters, such as plant height, number of leaves, leaf length and leaf width were measured every after two weeks. The number of tillers and number of days to tiller emergence were also recorded. For reproductive morphology, flower size and spatial arrangement of the flowers. The morphology of the flowers was observed and recorded using newly opened flowers that were still attached to the main plants. Additionally, the number of days for the first visible floral bud to emerge, the number of inflorescences per plant, and the percentage of flowering plants were noted. After harvesting, the fresh weights of the bulbs were measured. The dry weight of the bulbs was measured after $7 \times 24$ hours in the $60{ }^{\circ} \mathrm{C}$ oven.

All quantitative data were analyzed with ANOVA using SAS (Statistical Analysis System) v.9.0. Significant differ- 
ences between means were separated using the Duncan's Multiple Range Test at $\alpha=0.05$.

\section{Results and Discussion}

\section{Vegetative and Reproductive Morphology}

Eleutherine bulbosa is a bulbous plant, producing a clump of grass-like leaves (Figure 1A). The leaves are 30$50 \mathrm{~cm}$ long, 30-35 mm wide, linear lanceolate in shape, and smooth and entire along the margin. The stem is terete and consists of one long internode. A large cauline leaf grows at the apex subtending the inflorescence. The leaves of $E$. bulbosa last for 12 to 16 weeks before they start senescence. The plants start growing tillers at about 6 weeks after planting, with each tiller forming a bulb. The bulbs (Figure 1B) consist of layers, ovoid in shape, with striking deep redbrown colour, 40-50 $\mathrm{mm}$ length, 20-30 mm diameter, and 2.0- $2.5 \mathrm{~g}$ weight. The plants have shallow roots that are easily detached from the bulbs once harvested.

The inflorescence of E. bulbosa is rhipidium in shape, with $25-50 \mathrm{~mm}$ long peduncles that are borne in the axil of the cauline leaf. These peduncles have 3-4 umbels on the secondary axis, with each one consisting of a total of 10-12 florets that open in turn every day. Flowers are 20-30 $\mathrm{mm}$ long, ca. $20 \mathrm{~mm}$ in diameter, with $10-15 \mathrm{~mm}$ pedicels, and short-lived (i.e., they open early morning and wilt in the afternoon). The perianth is white, about $25 \mathrm{~mm}$ wide with yellow anthers and stigma (Figure 1C). The flowers do not have a notable scent. Fruits were not formed during the course of the study.

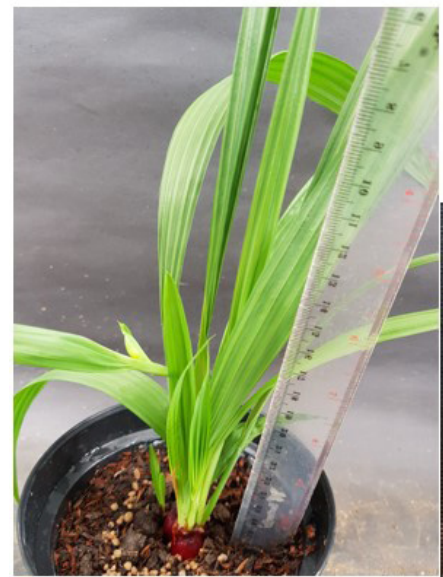

(A)

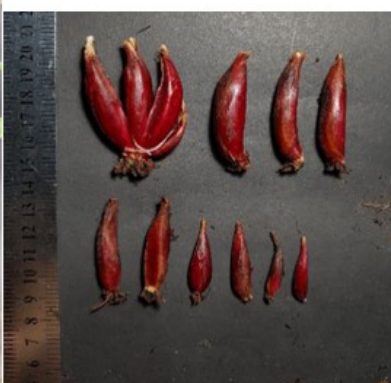

(B)

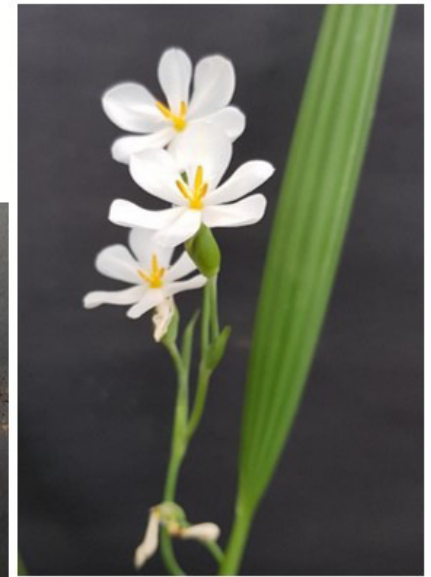

(C)

Figure 1. Growth habit (A), bulbs (B) and flowering branches (C) of E. bulbosa

The inflorescence of E. bulbosa is cymose with intrainflorescence, which is similar to those reported in Iris sibirica another species under the family Iridaceae. Eleutherine bulbosa can have 3-4 intra-inflorescences with 3-4 florets each, which develop as the plants age, whereas $I$. sibirica has only a maximum of two intra-inflorescences with 4-7 florets (Szollosi et al., 2010). Like other plants with cymose inflorescence, the main axis of E. bulbosa terminates in a flower. The first flower opens at the tip of the peduncle and the flower opens in basipetal succession. In this study, the first intra inflorescence developed 8 -10 weeks after planting, and 7 to 14 days later, the $2^{\text {nd }}$ and $3^{\text {rd }}$ intra-inflorescences were formed. Once the plants started flowering, the inflorescences continuously formed. Flower diameter were only measured on the first intrainflorescence and we noticed that it seems to decrease in measurement from the early to the later developing flowers. According to Hiraga and Sakai (2007) the morphology of a flower, including flower size, is highly affected by physiological factors including nutrition and environmental condition.

\section{Effect of Fertilizer on the Vegetative Growth of $E$. bulbosa}

The application of 2 or $3 \mathrm{~g}$ per pot NPK fertilizer promoted earlier shoot emergence by 1.3 days compared to those without fertilizer (control) and increased the number of tillers at week 6 compared to control and plants with fertilizer of $1 \mathrm{~g}$ per pot at week 6 (Table 1). However, at 18 weeks after planting the number of tillers in plants from all fertilizer treatments was similar (i.e. 3 times the number of tillers over control) (Table 1). 
Table 1. Vegetative growth of E. bulbosa with NPK fertilizer application.

\begin{tabular}{|c|c|c|c|c|c|c|c|c|c|}
\hline \multirow[t]{2}{*}{$\begin{array}{l}\text { NPK dose } \\
\text { (g per pot) }\end{array}$} & \multirow[t]{2}{*}{$\begin{array}{l}\text { Time of shoot emergence } \\
\text { (days after planting) }\end{array}$} & \multicolumn{2}{|c|}{$\begin{array}{l}\text { Leaf number per } \\
\text { plant at week }\end{array}$} & \multicolumn{2}{|c|}{$\begin{array}{c}\text { Leaf length }(\mathrm{mm}) \\
\text { at week }\end{array}$} & \multicolumn{2}{|c|}{$\begin{array}{c}\text { Leaf width }(\mathbf{m m}) \\
\text { at week }\end{array}$} & \multicolumn{2}{|c|}{$\begin{array}{c}\text { Tiller number at } \\
\text { week }\end{array}$} \\
\hline & & 4 & 16 & 4 & 8 & 4 & 8 & 6 & 18 \\
\hline 0 & $9.2 \mathrm{a}$ & $1.6 \mathrm{~b}$ & $6.0 \mathrm{c}$ & $20.0 \mathrm{~b}$ & $22.5 b$ & 1.7 & 1.7 & $0.2 \mathrm{c}$ & $5.3 b$ \\
\hline 1 & $8.7 \mathrm{ab}$ & $2.0 \mathrm{a}$ & $7.0 \mathrm{bc}$ & $22.7 \mathrm{a}$ & $24.1 \mathrm{ab}$ & 2.0 & 2.0 & $1.0 \mathrm{~b}$ & $14.7 \mathrm{a}$ \\
\hline 2 & $7.9 \mathrm{~b}$ & $2.0 \mathrm{a}$ & $8.0 \mathrm{~b}$ & $23.3 \mathrm{a}$ & $24.9 a$ & 1.9 & 2.5 & $2.9 \mathrm{a}$ & $15.5 \mathrm{a}$ \\
\hline 3 & $7.9 b$ & $2.0 \mathrm{a}$ & $9.3 \mathrm{a}$ & $22.9 a$ & $24.5 \mathrm{ab}$ & 2.0 & 2.0 & $3.4 \mathrm{a}$ & $15.5 \mathrm{a}$ \\
\hline $\mathrm{P}$ & $*$ & $* *$ & $* *$ & $* *$ & ns & ns & ns & $* *$ & $* *$ \\
\hline
\end{tabular}

Notes: Means followed by the different letters within the same column are significantly different by DMRT at $\alpha=5 \%$; ** highly significant, * = significant, $\mathrm{ns}=$ not significant

On the other hand, the use of $1 \mathrm{~g}$ per pot NPK fertilizer generally promoted better vegetative growth in plants as observed in the leaf number, leaf length and leaf width (Table 1). Adding $>1 \mathrm{~g} \mathrm{NPK}$ fertilizer per pot did not result in a significantly more leaf number. It should be pointed out though that when administered with $3 \mathrm{~g}$ of NPK per pot, the plants had 1-2 more leaves than those administered with 1 or $2 \mathrm{~g}$ NPK (Table 1).

\section{Effect of Fertilizer on the Reproductive Growth} of $E$. bulbosa

The generative phase of E. bulbosa started at 8 weeks after planting. Between 8 to 20 weeks, plants produced at least two inflorescences (Table 2). Fertilizer application did not significantly affect the time of emergence of the first inflorescence. Also, a high amount of NPK (3 g), plants showed delayed flowering and a reduced proportion of flowering plants were recorded (Table 2). At 16 weeks after planting, $90 \%$ of the plants that received 1 or $2 \mathrm{~g}$ per pot developed flowers, compared to only $83 \%$ in non-fertilized plants (Table 2).

At 8 weeks after planting (WAP), there were significantly more flowering plants in the treatment that had 1 g NPK (26.7\%) and 2 g NPK (40\%) compared to control $(10 \%)$ (Table 2). At 20 WAP, however, the total number of inflorescences was similar between control, 1 and $2 \mathrm{~g}$ NPK treatment (Table 2). The number of flowering plants that had $3 \mathrm{~g}$ NPK was consistently lower than control and those from other treatments at 8, 12 and 20 WAP (Table 2). A study on another Iridaceae species, Iris hexagona, showed that this species is relatively sensitive to salts in the medium, and that flowering was delayed with the presence of $4 \mathrm{~g} \mathrm{~L}$ of salts (Van Zandt and Mopper, 2002). The delayed flowering in I. hexagona in Van Zandt and Mopper (2002) study was similar to the response of $E$. bulbosa to the high NPK treatment ( 3 g per plant) in our study.

\section{Bulb Production in E. bulbosa}

The application of NPK resulted in significant increase in fresh and dry weight and the numbers of bulbs in E. bulbosa. The highest bulb production was observed in plants administered with $2 \mathrm{~g}$ NPK. The application of $>2 \mathrm{~g}$ fertilizer per pot did not increase bulb production further (Table 3 ). The water content of the bulbs was similar between all treatments (Table 3).

Table 2. Time of flower emergence, percentage of flowering plant and total number of inflorescences per plant in $E$. bulbosa with and without NPK treatment.

\begin{tabular}{|c|c|c|c|c|c|}
\hline NPK (g per pot) & $\begin{array}{c}\text { Time of the first inflorescence } \\
\text { emergence (WAP) }\end{array}$ & \multicolumn{3}{|c|}{ Flowering plants (\%) } & $\begin{array}{c}\text { Total of number of inflorescence } \\
\text { per plant at 20 WAP }\end{array}$ \\
\hline & & 8 WAP & 12 WAP & 16 WAP & \\
\hline 0 & 12.8 & $10.0 \mathrm{c}$ & $43.3 \mathrm{a}$ & $83.3 \mathrm{a}$ & $1.9 \mathrm{ab}$ \\
\hline 1 & 11.6 & $26.7 \mathrm{~b}$ & $50.0 \mathrm{a}$ & $93.3 \mathrm{a}$ & $2.1 \mathrm{a}$ \\
\hline 2 & 10.8 & $40.0 \mathrm{a}$ & $43.3 \mathrm{a}$ & $90.0 \mathrm{a}$ & $2.1 \mathrm{a}$ \\
\hline 3 & 12.2 & $20.0 \mathrm{~b}$ & $23.3 \mathrm{~b}$ & $53.3 \mathrm{~b}$ & $1.5 \mathrm{~b}$ \\
\hline
\end{tabular}

Notes: Means followed by the different letters within the same column are significantly different by DMRT at $\alpha=5 \%$. WAP: weeks after planting 
Table 3. Bulb production in E. bulbosa with NPK fertilizer application

\begin{tabular}{|c|c|c|c|c|c|}
\hline $\begin{array}{c}\text { NPK } \\
\text { (g per pot) }\end{array}$ & $\begin{array}{c}\text { Shoot fresh weight } \\
\mathbf{( g )}\end{array}$ & Number of bulbs & $\begin{array}{c}\text { Bulb fresh weight } \\
\mathbf{( g )}\end{array}$ & $\begin{array}{c}\text { Bulb dry weight } \\
\mathbf{( g})\end{array}$ & $\begin{array}{c}\text { Bulb water } \\
\text { content (\%) }\end{array}$ \\
\hline 0 & $31.5 \mathrm{c}$ & $6.0 \mathrm{~b}$ & $12.5 \mathrm{~b}$ & $5.4 \mathrm{~b}$ & 53.0 \\
\hline 1 & $74.1 \mathrm{~b}$ & $17.6 \mathrm{a}$ & $40.7 \mathrm{a}$ & $19.8 \mathrm{a}$ & 53.7 \\
\hline 2 & $83.3 \mathrm{a}$ & $18.7 \mathrm{a}$ & $44.9 \mathrm{a}$ & $21.0 \mathrm{a}$ & 52.2 \\
\hline 3 & $83.1 \mathrm{a}$ & $19.2 \mathrm{a}$ & $44.1 \mathrm{a}$ & $21.7 \mathrm{a}$ & 52.3 \\
\hline F-test & $* *$ & $* *$ & $* *$ & $* *$ & $\mathrm{~ns}$ \\
\hline
\end{tabular}

Notes: Means followed by the different letters within the same column are significantly different by DMRT at $\alpha=5 \%$. WAP: weeks after planting** $=$ highly significant, * = significant

The composition of NPK fertilizer applied to E. bulbosa in this study was determined based on the levels of $\mathrm{N}$ and $\mathrm{K}$ in Iridaceae leaves as reported in Engin et al. (1998) who reported that $\mathrm{N}$ and $\mathrm{P}$ concentrations of the above-ground parts of Iridaceae were high in the vegetative stage, and decreased once the plants had entered the generative stage. NPK 16-16-16 in our study was applied at the vegetative stage, and 12-12-17 was applied at the generative stage. The higher concentrations of nitrogen during vegetative period can be attributed to the active growth at this stage, resulting in partitioning of the nutrients to the above-ground plants. Increasing the dosage of potassium from 36 to $180 \mathrm{~kg} \mathrm{~K} \mathrm{O}_{2}$ per ha significantly increased onion yield, with bulb production at $180 \mathrm{~kg} \mathrm{~K}_{2} \mathrm{O}$ per ha being $22.8 \%$ higher than without fertilizer, while the leaf potassium contents of onion with no fertilizers was still within the sufficiency range (Marrocos et al., 2018). In our study, we did not notice the symptoms of $\mathrm{N}, \mathrm{P}$ or $\mathrm{K}$ deficiency in the control plants. All plants grew normally.

We noted that the root system of E. bulbosa is relatively shallow. Shallow root systems have been recorded in other bulbous crops, including onion (Khokhar, 2019). The root growth of E. bulbosa is concentrated within $20 \mathrm{~cm}$ of the soil depth, thus the potential for nitrogen losses due to leaching is high, particularly in areas and season with high rain intensity. In this study, fertilizer was applied twice and the plants grew well. Machado and Bryla (2020) highlighted the importance of applying nitrogen at bulbing stage of onion to increase nitrogen uptake, yield and bulb size.

The nitrogen use efficiency decreased in response to each increment of added N (Xu et al., 2020). Therefore, application of appropriate rate $\mathrm{N}$ fertilizer could improve $\mathrm{N}$ use efficiency, and at the same time reducing the cost of chemical input and risk of $\mathrm{N}$ losses to the environment. It is possible that with multiple $\mathrm{N}$ application at lower dosages the plants will grow better and produce larger bulbs. Further study is required to assess growth and bulb production of E. bulbosa whilst improving $\mathrm{N}$ fertilizer use efficiency. The information from this study can be useful for commercial production of E. bulbosa and potentially to other bulb crops that have shallow root system.

\section{Conclusions}

Eleutherine bulbosa has grass-like leaves of $30-50 \mathrm{~cm}$ in length; they start growing tillers at 6 weeks, with each tiller forming a bulb. E. bulbosa has a cymose rhipidium inflorescence with 3-4 umbels, each consists of 10-12 florets that opens in turn every day. The florets have white perianth with anthers and stigma, and are short-lived. Application of NPK fertilizer at $1 \mathrm{~g}$ per pot had promoted earlier shoot emergence and vegetative growth, including plant height, leaf number, leaf size, number of tillers, and had tripled the bulb production compared to without fertilizer. Therefore, low dosages of fertilizer are recommended to cultivate E. bulbosa.

\section{Author Contribution}

NMAW: creation of idea, research orientation, suggestions, and monitoring the entire experiment, preparation of the manuscript. NM: installation of the experiment, conduction, documentation. KK: research orientation, suggestions, monitoring the experiment, statistical analysis, preparation of the manuscript.

\section{References}

BAHTIAR, A.; ANNISA, R. Effects of Dayak onion bulbs (Eleutherine bulbosa Mill. Urb) on bone development of the hipoestrogen model rat. Pharmacognosy Journal, v.10, n.2, p. 299-303, 2018. https://doi.org/10.5530/ pj.2018.2.52

BINGHAM, M.G.; WILLEMEN, A.; WIGHTMAN, N.; WURSTEN, B.T.; BALlingS, P.; HYDE, M.; PALGRAVE, M.C. 2020. Flora of Zambia. Available at: www. zambiaflora.com. Accessed on: $1^{\text {st }}$ Jun 2020.

CHEN, D.L.; HU, M.G.; LIU, Y.Y.; LI, R.T.; YU, M.; XU, X.D.; MA, X.M. New naphthalene derivatives from the bulbs of Eleutherine americana with their protective effect on the injury of HUVECS. Molecules, v.23, n.9, p.2111, 2018. https://doi.org/10.3390/molecules23092111 
CLINTON, C.; SPARGO, J.; FISHEL, S. Strong acid extraction methods for total phosphorus in soils: EPA method 3050B and EPA method 3051. Agricultural and Environmental Letters, v.2, p.160037, 2017. https://doi. org./10.2134/ael2016.09.0037

COUTO, C.L.L.; MORAES, D.F.C.; CARTAGENES, M.S.S.; AMARAL, F.M.M.; GUERRA, R.N. Eleutherine bulbous (Mill.) Urb.: A review study. Journal of Medicinal Plants Research, v.10, n.21, p.286-297, 2016. https:// doi.org/10.5897/JMPR2016.6106

ENGIN, A.; KANDEMIR, N.; SENEL, G.; OZKAN, M. An autecological study on Iris pseudacorus L. (Iridaceae). Turkish Journal of Botany, v.22, p.335-340, 1998.

HIRAGA, T.; SAKAI, S. The effects of inflorescence size and flower position on biomass and temporal sex allocation in Lobelia sessiliflora. Plant Ecology, v.188, n.2, p.205214, 2007. https://doi.org/10.1007/s11258-006-9157-9

JIANG, H.; MAN, W.J.; HOU, A.J.; YANG, L.; XING, X.D., YAN, M.L.; GUO, X.Y., YANG, L. The chemical constituents from the active fractions of Eleutherine bulbosa with their antimicrobial activity. Natural Product Research, v.34, n.12, p.1743-1749, 2020. https://doi: $10.1080 / 14786419.2018 .1530229$

KAMARUDIN, A.A.; ESA, N.M.; SAAD, N.; SAYUTI, H.S.; RAZAK, N.A.A. Heat assisted extraction of phenolic compounds from Eleutherine bulbosa (Mill.) bulb and its bioactive profiles using response surface methodology. Industrial Crops and Products, v.144, p.112064, 2020. https://doi.org/10.1016/j.indcrop.2019.112064

KHOKHAR, K.M. Mineral nutrient management for onion bulb crops, a review. The Journal of Horticultural Science and Biotechnology, v.94, n.6, p.707-717, 2019. https://doi.org/10.1080/14620316.2019.1613935

KUNTORINI, E.M.; DEWI, M.; MISRINA, M. Anatomical structure and antioxidant activity of red bulb plant (Eleutherine americana) on different plant age. Biodiversitas, v.17, n.1, p.229-233, 2016. https://doi.org/10.13057/ biodiv/d170123

MALHEIROS, D.S.; L.C.; MELLO, J.C.P.D.; BARBOSA, W.L.R. Eleutherine plicata - quinones and antioxidant activity. Intech, v.14, p.323-338, 2015. https://doi. org/10.5772/59865

MACHADO, R.M.A.; BRYLA, D.R. Nitrogen requirements at bulb initiations for production of intermediateday onions. Acta Horticulturae, v.1142, p.67-73, 2016. https://doi.org/10.17660/ActaHortic.2016.1142.11
MARROCOS, S.T.; GRANGEIRO, L.C.; RIBERIRO, R.M.P.; DE SOUSA, V.F.L.; CORDERIRO, C.J. Potassium fertilization for optimization of onion production. Revista Caatinga, v.31, n.2, p.379-384, 2018. https://doi. org/10.1590/1983-21252018v31n214rc

NOOSAR, R.; ADI, T. 2015. Budidaya bawang dayak mudah dan murah. Available at: //peluangusaha.kontan. co.id/news/budidaya-bawang-dayak-mudah-dan-murah-2. Accessed on: $2^{\text {nd }}$ Dec 2020.

PREETHY, A.S.; VIVEK, P.; REMADEVI, R. Preliminary morphological and phytochemical screening of bulb of Eleutherine bulbosa Mill. Urb. Global Journal of Research on Medicinal Plants \& Indigenous Medicine, v.5, n.10, p.267-273, 2016.

PURNAMASARI, A.; BAHTIAR, A. Effect of Dayak onion (Eleutherine bulbosa Mill.) Urb) on uterine wall and lipid profiles of ovariectomized rat. Journal of Biological Science, v.18, n.1, p.1-6, 2018. https://doi.org/10.3844/ojbsci.2018.1.6

PUTRA, Y.M.P. Budidaya bawang Dayak sederhana dan menjanjikan. 2018. Available at: https://republika.co.id/berita/ p2aplz284/budi-daya-bawang-dayak-sederhana-dan-menjanjikan.2018. Accessed on: $5^{\text {th }}$ Oct 2020.

RANI, V.S.; NAIR, B.R. GC MS Analysis of ethyl acetate extract of Eleutherine bulbosa (Urban) Miller (Iridaceae). International Journal of Pharmaceutical Sciences and Research, v.7, n.4, p.1729-1733, 2016.

SHI, P.; DU, W.; WANG, Y.Y.; TENG, X.; CHEN, X.D.; YE, L.B. Total phenolic, flavonoid content, and antioxidant activity of bulbs, leaves, and flowers made from Eleutherine bulbosa (Mill.) Urb. Food Science and Nutrition, v.7, n.1, p.148-154, 2019. https://doi.org/10.1002/fsn3.834

SZOLLOSI, R. Intra-inflorescence variations in floral morphological and reproductive traits of Iris sibirica L. Acta Biologica Szegediensis, v.54, n.2, p.103-110, 2010.

XU, A.; LI, L.; XIE, J.L WANG, WX.; COULTER, J.A.; LIU, C.; WANG, L. Effect of long-term nitrogen addition on wheat yield, nitrogen use efficiency, and residual soil nitrate in a semiarid area of the Loess Plateau of China. Sustainability, v.12, p.1735, 2020. https://doi.org/10.3390/ su12051735

VAN ZANDT, P.A.; MOPPER, S. Delayed and carryover effects of salinity on flowering in Iris hexagona (Iridaceae). American Journal of Botany, v.89, n.11, p.1847-1851, 2002. 10.3732/ajb.89.11.1847 